\title{
Multifocal Extramedullary Plasmocytoma of the Sinonasal Region: a Case Report and Literature Review
}

\author{
Plasmocitoma Multifocal Extramedular de la Región Sinonasal: \\ Reporte de un Caso y Revisión de la Literatura
}

\author{
Ilson Sepúlveda*; Loreto Spencer; Rodrigo Klaassen*; Enrique Platín ${ }^{* \star *}$ \\ Cesar García ${ }^{\star \star \star *} ;$ Ornella Salvatori ${ }^{* \star * \star * *}$ \& David Ulloa
}

SEPÚlVEDA, I.; SPENCER, L.; KLAASSEN, R.; PLATÍN, E.; GARCÍA, C.; SALVATORI, O. \& ULLOA, D. Multifocal extramedullary plasmocytoma of the sinonasal region: a case report and literature review. Int. J. Odontostomat., 7(3):427432, 2013.

ABSTRACT: We report on a patient who presented to ENT services with right side epistaxis, frontal lobe headache, right infraorbital pain and the feeling of having a stuffy nose. CT and MRI were performed and later a biopsy confirmed the presence of sinonasal plasmocytoma. The Head and Neck oncology committee recommended radiotherapy as the choice of treatment. At the present time the patient is being followed on scheduled medical visits.

KEY WORDS: CT, MRI, plasmocytoma, sinonasal, extramedullary, tumor.

\section{INTRODUCTION}

Multiple Myeloma (MM), Solitary Bone Plasmocytoma (SBP) and Extramedullary Plasmocytoma (EMP) are plasmatic cell tumors that can be grouped in one category. Only $30 \%$ of extramedullary plasmocytomas evolve into multiple myelomas, while most bone plasmocytomas do (Gross et al., 2004; Seoane et al., 2003) Schridde described the first extramedullary plasmocytoma in 1905 (Schridde, 1905). Extramedullary plasmocytomas represent less than $1 \%$ of all head and neck neoplasms and $4 \%$ of all non-epithelial nasal tumors (Kanotra \& Lateef, 2010). Extramedullary plasmocytomas are usually confined to soft tissues without bone involvement (Mcafee et al., 2004) and are produced by monoclonal plasmatic cell proliferation. Occurrence can happen at any age, but the majority appear more frequently in the fifth and seventh decades (Jaswal et al., 2008; Megat Shiraz et al., 2008; Lomeo et al., 2007). Extramedullary plasmocytoma affects more males than females and studies have reported $4: 1$ and 2:1 ratios.
Lesions are predominantly seen in the upper nasal and GI tract affecting the submucosal tissue of the nasal cavity and paranasal sinuses $43.8 \%$ of the time, nasopharynx $18.3 \%$, oropharynx $17.8 \%$ and larynx 11.1\% (Megat Shiraz et al.; Lomeo et al.; Alexiou et al., 1999) Affected regions could present as solitary or multiple masses but present more commonly as solitary lesions.

Plasmocytomas can be characterized by the degree of atypia as follows: Low or grade 1 intermediate or grade 2 and advanced or grade 3 . Also, based on laboratory tests such as blood, urine, bone scans, bone marrow test and radiographic studies, it can be staged as, 1 or localized; stage 2 when there is local invasion and lymph node involvement and stage 3 when metastatic invasion is present.

There are no specific clinical manifestations or symptomatology since it varies depending on tumor

Oral, Maxillofacial, Head and Neck Radiologist, Otolaryngology-Head and Neck Surgery Service, General Hospital of Concepcion, Professor of Oral and Maxillofacial Radiology, Finis Terrae University School of Dentistry, Santiago, Chile.

** Physician Pathologist, Pathology Department, General Hospital of Concepción, Concepcion, Chile.

*.* Professor of Oral and Maxillofacial Radiology, University of North Carolina School of Dentistry, Chapel Hill, N.C.

**** Physician Radiation Oncologist, Oncology Service, General Hospital of Concepcion.

General Dentist, Concepción, Chile

${ }^{*} \times+*+* * *$ Medicine Student. 
location. The most common symptom is the presence of a lump or a sessile or pedunculated soft tissue mass. These lesions are circumscribed or infiltrating in $80 \%$ of the cases. Nasal obstruction and pressure is present in $35 \%$ of the cases, epistaxis $35 \%$, pain $20 \%$, ocular proptosis and blurry vision $15 \%$, rhinorrea $10 \%$, regional lymphadenopathy $10 \%$, facial nerve paralysis $5 \%$ with symptoms often lasting from 4 to 5 months (Miller et al., 1998).

Diagnosis of Extramedullary Plasmocytoma is achieved from a biopsy of the lesion and from histologically and immunohistochemical analysis. It is based on the presence of plasmatic cells showing birefraction with Congo red stain and presenting cytologically as benign tracts however, immunohistochemical tests demonstrate its monoclonality pointing to its neoplastic nature (González et al., 2011). Neoplastic cell usually produce a large chain of monoclonal immunoglobulin that can be detected in both blood and urine (Pinto et al., 2007). Radiologic imaging is crucial in the evaluation and localization of the size of the lesion. Magnetic Resonance Imaging (MRI) helps to determine the extent of soft tissue involvement often showing up as hyperintense lesions in T1 relaxation and homogeneously enhancing after Gadolinium contrast administration (Waldro \& Mitchell, 1988; Cakir et al., 2003). In Computed Tomography (CT), plasmocytomas are seen as radiopaque lesions, with homogeneous contrast enhancement.

Due to the high radiosensitivity of the tumor the recommended standard treatment is Radiation therapy. Depending on the size of the tumor, the therapeutic dose ranges from 40 to 50 Gys, for 4 to 6 weeks. Surgery could be used as the primary treatment if the size and location are favorable. In some cases, a combination of surgery and radiotherapy could be used depending on the possibility of resecting the lesion (Liebross et al., 1999). Surgery is the best choice in cases of recurrence, while chemotherapy is indicated only when there are multiple and refractory lesions or when recurrence cannot be treated surgically (Soutar et al., 2004).

It has been reported that $22 \%$ of the cases that have been adequately treated for multiple extramedullary plasmocytoma in the superior gastro intestinal tract have resulted in a local recurrence (Kanotra \& Lateef). Survival rate has been reported to be 10 years for $70 \%$ of those afflicted with the disease (Knowling et al., 1983). The best prognostic indicator for multiple extramedullary plasmocytoma is weather the lesion progresses into multiple myeloma. Progression into multiple myeloma occurs in $15 \%$ to $20 \%$ of the cases and this is often associated with a poor prognosis reducing the survival rate from 10 years to 20 months (Fu \& Perzin, 1978; Shreif et al., 2001) The prognosis is even worse when there are multiple lesions present (Mochimatsu et al., 1993; Wanebo et al., 1966).

\section{CASE REPORT}

We report on a 52-year-old male patient who presented to ENT services without a significant clinical history. However, he complained of having the following symptoms; right side epistaxis, frontal lobe headache, right infraorbital pain and the feeling of having a stuffy nose. CT and MRI were performed with the $\mathrm{CT}$ revealing a solid and expansive mass occupying the right nasal fossa and left maxillary sinus. The mass was associated with inflammatory changes and dense secretions emerging from the right maxillary sinus (Fig. 1). The mass demonstrated a moderate enhancement after intravenous contrast was given (Fig. 2). The mass revealed erosion of the cribriform plate producing dehiscence without a clear extension into the anterior cranial fossa. Destruction of the nasal conchae, medial orbital wall and right maxillary sinus can be seen (Fig. 3 ).

MRI revealed an expansive process of low intensity in the right nasal fossa suggestive of high cellular activity (Figs. 4 and 5), and heterogeneous enhancement after gadolinium intravenous injection suggestive of necrosis in the central area. Also, a Focal

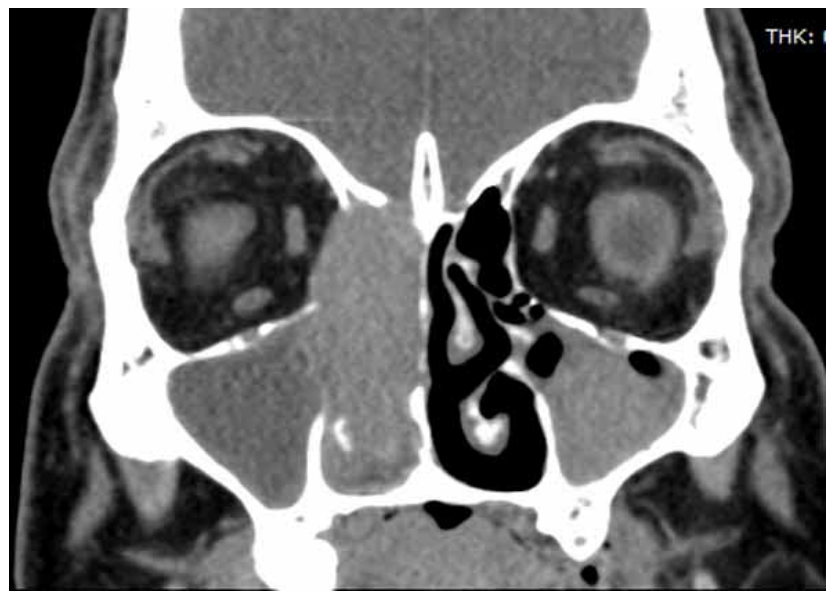

Fig. 1 Invasion of the mass is seen affecting the soft tissue in the right nasal fossa and right maxillary sinus. 


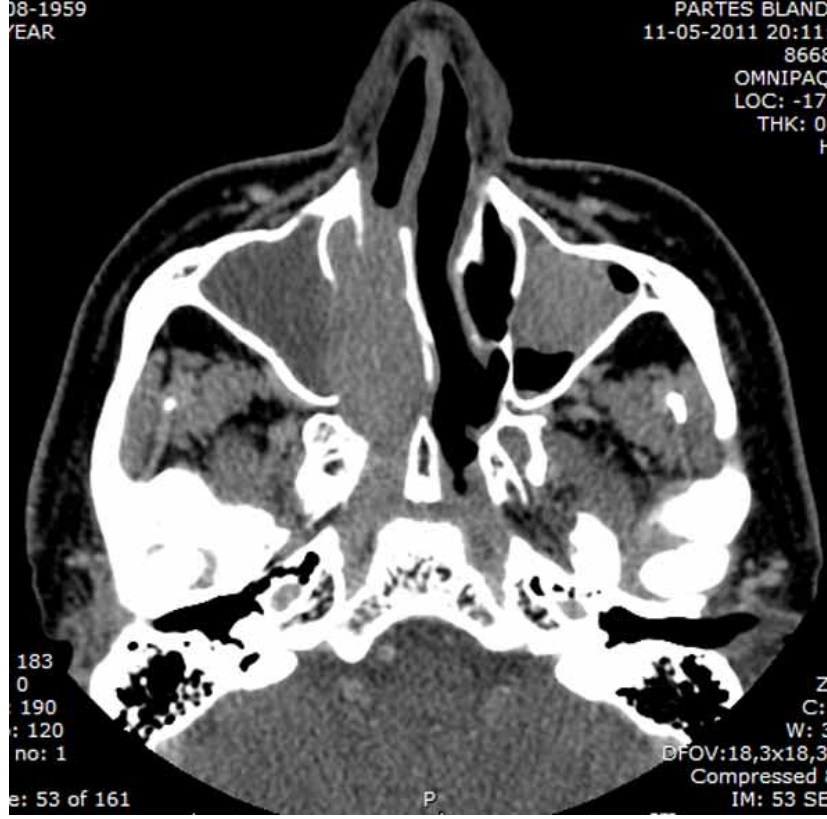

Fig. 2 Image following contrast media injection shows poor to moderate enhancement of the region.

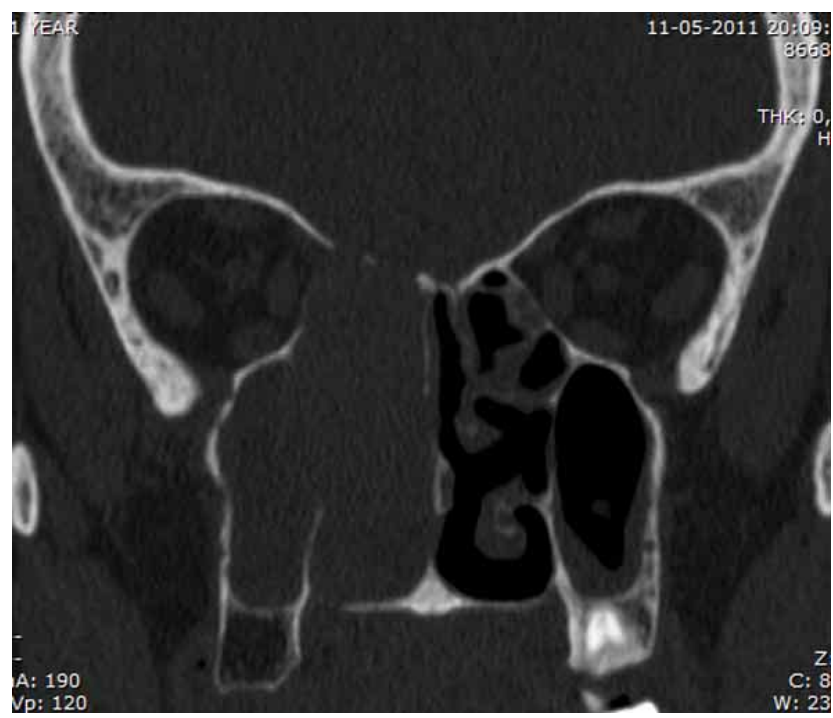

Fig. 3 Erosion of the cribriform plate is seen affecting the right nasal conchae, lateral wail of the orbit and right maxillary sinus.

lesion with rounded contours in the left maxillary sinus was seen with moderate enhancement after contrast injection. Mucosal thickening in the right maxillary sinus and the appearance of secretions were seen in the central (Figs. 6 and 7).

A biopsy was performed and the immunohystochemical analysis revealed positive results for CD 138 and Vimentine; negative results for

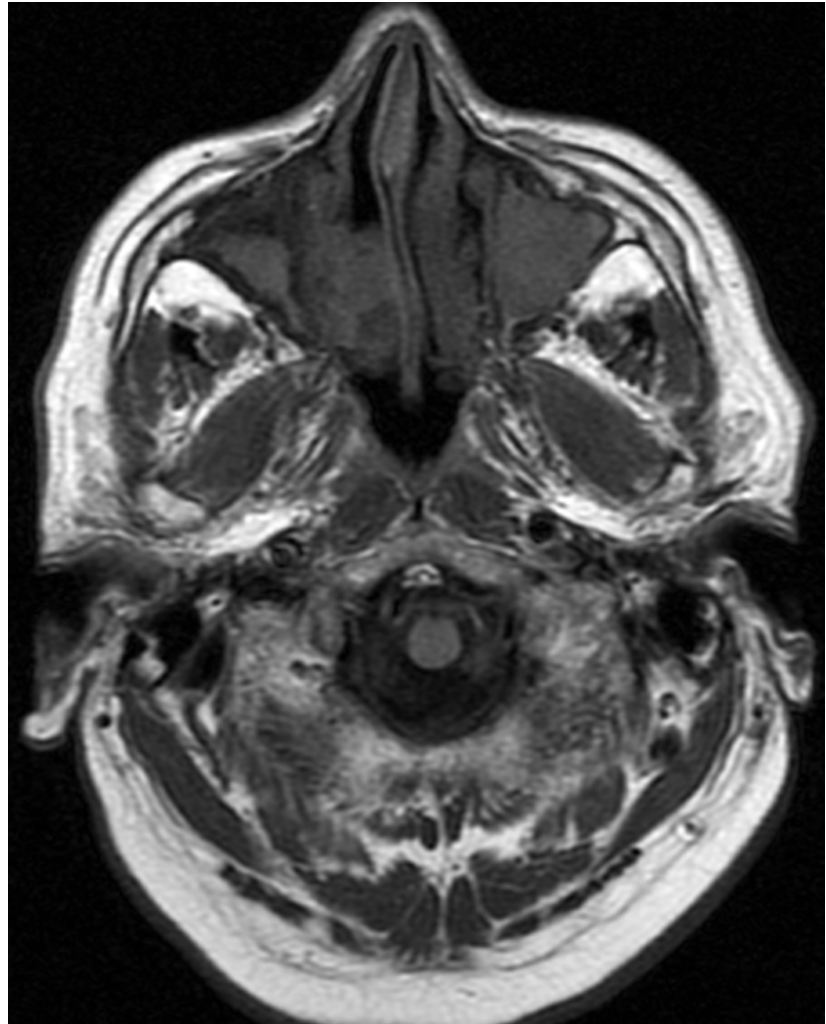

Fig. 4. T1 weighted image reveal masses in the right nasal and maxillary sinus areas.

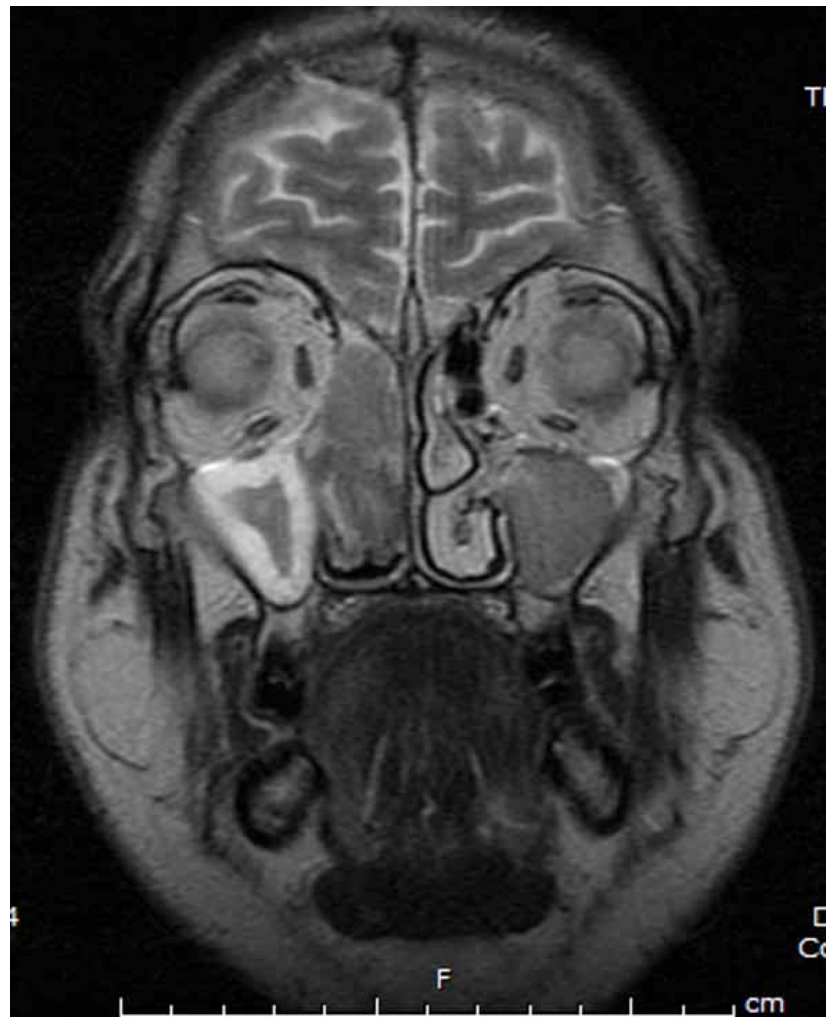

Fig. 5. T2 weighted image shows the presence of mucus occupying the right maxillary sinus. 


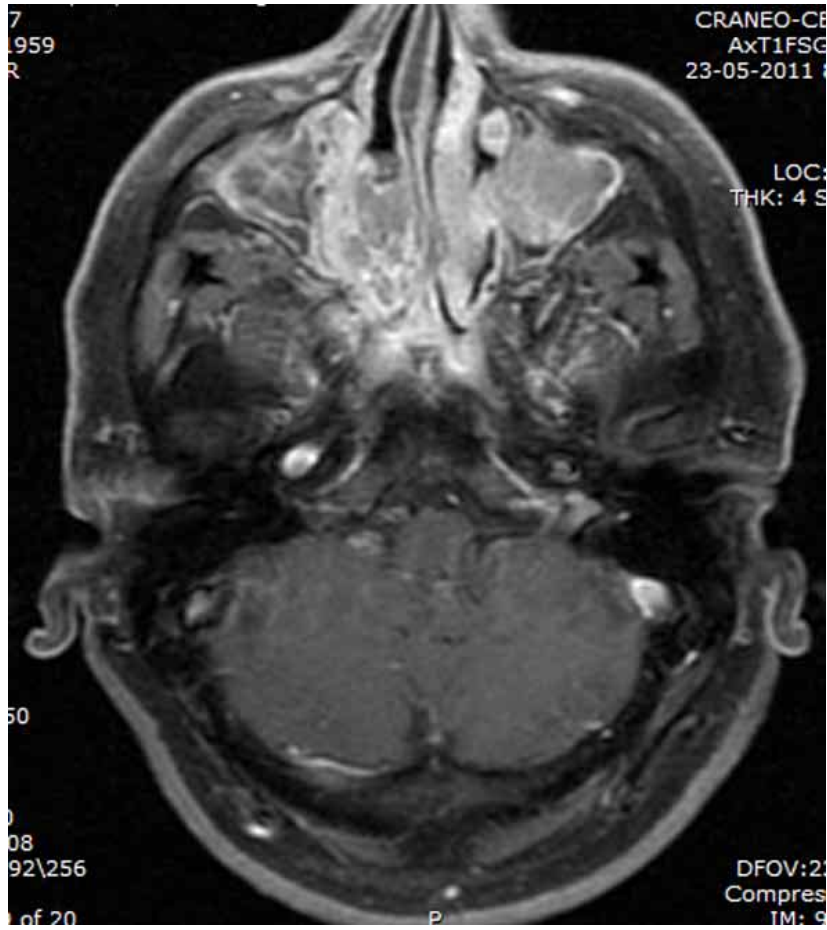

Fig. 6. T1 weighted image demonstrate heterogeneous areas of the mass following injection of contrast media.

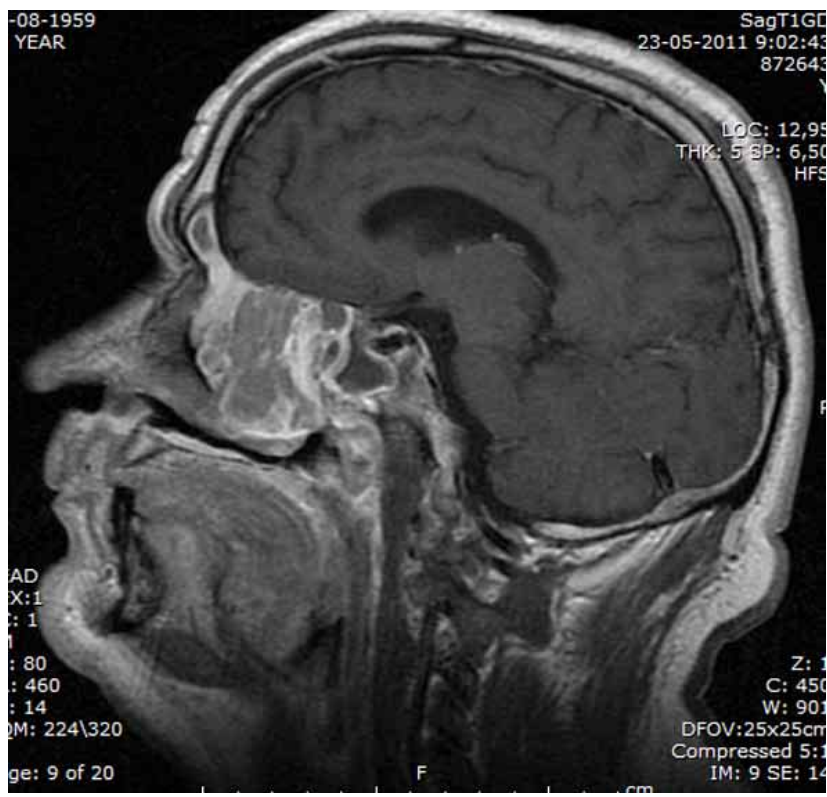

Fig. 7. Post gadolinium contrast media injection image fails to reveal anterior cranial fossae involvement.

S-100 and Synaptophysin. Ultimately the histopathology revealed "Maxillary and Nasal Plamocytoma" (Fig 8)

A consultation with the Hematology service to rule out Multiple Myeloma was carried out and

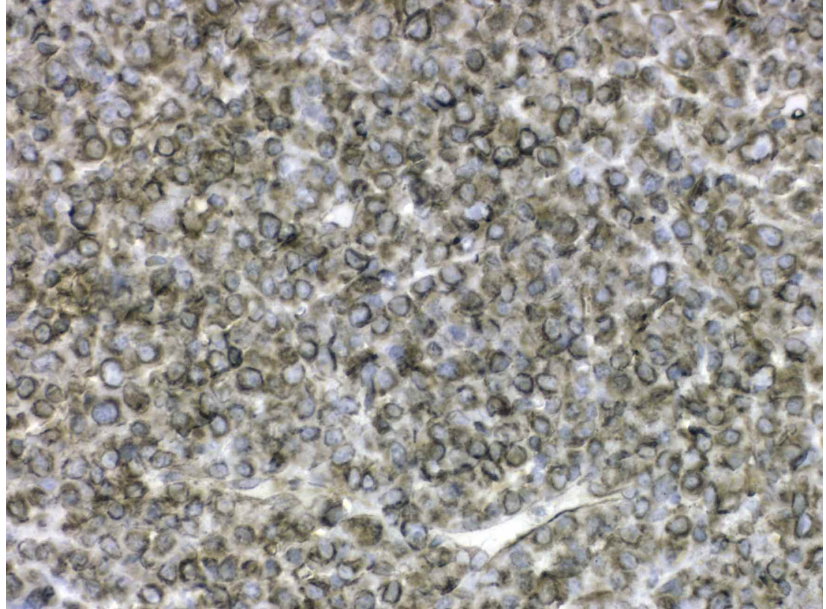

Fig. 8. Positive results for Vimentine.

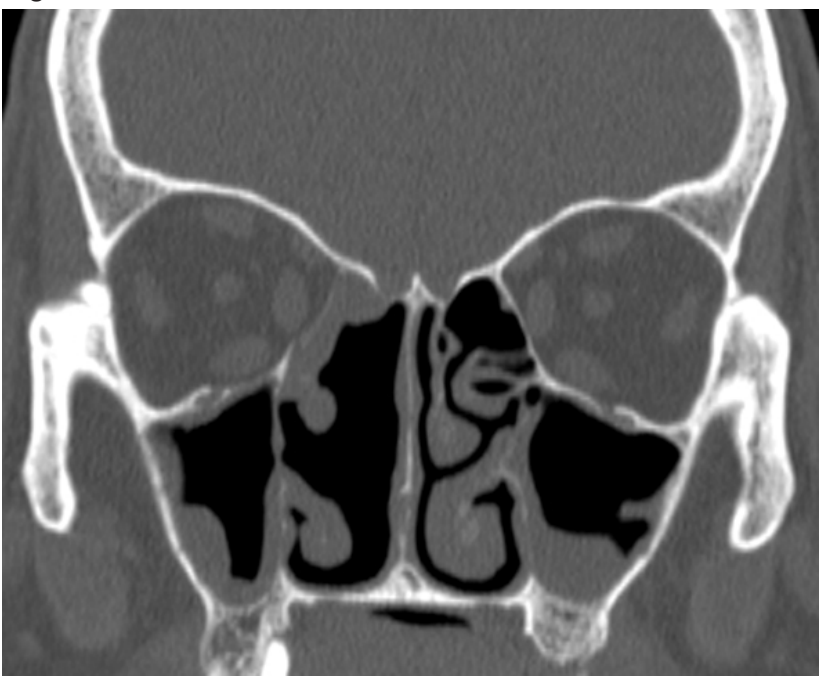

Fig. 9. Follow up CT shows resolution of the mass and thickening of the mucous membrane in maxillary sinus regions.

consequently The Head and Neck Cancer Committee recommended radiation therapy resulting in excellent results as seen in Figure 9. Currently the patient is evaluated on a regular basis to assess his progress.

\section{CONCLUSION}

Extramedullary Plasmocytoma are tumors that present predominantly in the upper respiratorydigestive tract. Clinical signs and symptoms are nonspecific and could vary due to tumor location. The most common symptom is the presence of tumefaction or soft tissue mass. The final Diagnosis is based on immunohystochemical and histological studies showing the presence of plasmatic cells. Imaging is crucial for 
evaluating the location and size of the lesion differentiating it from adjacent inflammatory processes Standard treatment is radiation therapy due to the radiosensitivity of the lesions. The 10-year survival rate is $70 \%$. Progression of the lesion to Multiple Myeloma is associated with a poor prognosis reducing the survival rate approximately to 20 months from the time it changes.

SEPÚlVEDA, I.; SPENCER, L.; KLAASSEN, R.; PLATíN, E.; GARCÍA, C.; SALVATORI, O. \& ULLOA, D. Plasmocitoma multifocal extramedular de la región sinonasal: reporte de un caso y revisión de la literatura. Int. J. Odontostomat., 7(3):427432, 2013.

RESUMEN: Se reporta el caso de un paciente que se presentó en el servicio de Otorrinolaringología con epistaxis, cefalea del lóbulo frontal derecho, dolor infraorbitario derecho y la sensación de tener la nariz tapada. Se realizaron TC y RNM, y luego una biopsia confirmó la presencia de un plasmocitoma nasosinusal. El comité de oncología de cabeza y cuello recomendó radioterapia como tratamiento de elección. En la actualidad, el paciente está en siguimiento y control en las visitas médicas regulares.

PALABRAS CLAVE: tomografía computarizada, resonancia nuclear magnética, plasmocitoma, nasosinusal, extramedular, tumor.

\section{REFERENCES}

Alexiou, C.; Kau, R. J.; Dietzfelbinger, H.; Kremer, M.; Spiess, J. C.; Schratzenstaller, B. \& Arnold, W. Extramedullary plasmacytoma: tumor occurrence and therapeutic concepts. Cancer, 85(11):2305-14, 1999.

Cakir, E.; Karaarslan, G.; Usul, H.; Baykal, S. \& Arslan, E. Solitary plasmacytoma with intracranial intraorbital and, paranasal sinus extension. J. Clin. Neurosci., 10(2):2668, 2003.

Fu, Y. S. \& Perzin, K. H. Nonepithelial tumors of the nasal cavity, paranasal sinuses and nasopharynx. A clinicopathologic study. IX. Plasmacytomas. Cancer, 42(5):2399-406, 1978.

González, I.; Díez, L; Rodriguez, N. \& Pallas, E.; Extramedullary Plasmacytoma of the Larynx. A Case Report. Acta Otorrinolaringol., 62(4):320-2, 2011.

Gross, M.; Eliashar, R.; Maly, B. \& Sichel, J. Y. Maxillary sinus plasmacytoma. Isr. Med. Assoc. J., 6(2):119-20, 2004.

Jaswal, A.; Biswas, G.; Sikder, B.; Das, A. \& Nandi, T. Extramedullary Plasmacytoma of Maxillary Sinus in 10year-old girl: A rare presentation. Int. J. Pediatr. Otorhinolaryngol. Extra, 3(3):143-6, 2008.

Kanotra, S. \& Lateef, M. Extramedullary Plasmacytoma of The Nasal Cavity. J. Otorhinolyngol., 11(2), 2010. Available in: http://ispub.com/IJORL/11/2/9209

Knowling, M. A.; Harwood, A. R. \& Bergsagel, D. E. Comparison of extramedullary plasmacytomas with solitary and multiple plasma cell tumors of bone. J. Clin. Oncol., 1(4):255-62, 1983.
Liebross, R. H.; Ha, C. S.; Cox, J. D.; Weber, D.; Delasalle, K. \& Alexanian, R. Clinical course of solitary extramedullary plasmacytoma. Radiother. Oncol., 52(3):245-9, 1999.

Lomeo, P. E.; McDonald, J. E.; Finneman, J. \& Shoreline. Extramedullary plasmacytoma of the nasal sinus cavities. Am. J. Otolaryngol., 28(1):50-1, 2007.

Mcafee, M.; Valvassori, G. \& Becker, M. Imaging of the Head and Neck. $2^{\text {nd }}$ ed. Stuttgart, Thieme, 2004.

Megat Shiraz, M. A.; Jong, Y. H. \& Primuharsa Putra, S. H. Extramedullary plasmacytoma in the maxillary sinus. Singapore Med. J., 49(11):e310-1, 2008.

Miller, F. R.; Lavertu, P.; Wanamaker, J. R.; Bonafede, J. \& Wood, B. G. Plasmacytomas of the head and neck. Otolaryngol. Head Neck Surg., 119(6):614-8, 1998.

Mochimatsu, I.; Tsukuda, M.; Sawaki, S. \& Nakatani, Y. Extramedullary Plasmacytoma of the Larinx. J. Laryngol. Otol., 107(11):1049-51, 1993.

Pinto, L. S.; Campagnoli, E. B.; Leon, J. E.; Lopes, M. A. \& Jorge, J. Maxillary lesion presenting as a first sign of multiple myeloma: case report. Med. Oral Patol. Oral Cir. Bucal, 12(5):E344-7, 2007.

Schridde, H. Weitere Untersuchungen Über die Kornelungen der Plasmazellen. Centralbl. Allg. Pathol. Anat., 16:4335,1905 .

Seoane, J.; Aguirre, J.; Esparza, G.; Suárez, M.; Campos, J. \& Pomareda, M. Espectro de las Neoplasias de Células 
Plasmáticas en el Ámbito de la Patología Maxilofacial. Med. Oral, 8:269-80, 2003.

Shreif, J.; Covonas, P. \& Mastonikolis, N. Extramedullary Plasmacytoma of the Nasal Cavity. Otolaryngol. Head Neck Surg., 124:119- 20, 2001.

Soutar, R.; Lucraft, H.; Jackson, G.; Reece, A.; Bird, J.; Low, E.; Samson, D.; Working Group of the UK Myeloma Forum; British Committee for Standards in Haematology \& British Society for Haematology. Guidelines on the diagnosis and management of solitary plasmacytoma of bone and solitary extramedullary plasmacytoma. Clin. Oncol. (R. Coll. Radiol.), 16(6):405-13, 2004.

Waldron. J. \& Mitchell, D. Unusual Presentations of Extramedullary Plasmacytoma in the Head and Neck. J. Laryngol. Otol,, 102(1):102-4, 1988.

Wanebo, H.; Geller, W. \& Gerald, F. Extramedullary Plasmacytoma of the Upper Respiratory Tract. Recurrence After Latency of Thirty-six years. N. Y. State J. Med., 66(9):1110-3, 1966.
Correspondence to:

Dr. Ilson Sepulveda

Otolaryngology-Head and Neck Surgery Service

General Hospital of Concepcion

San Martin Av. No 1436

Concepción

CHILE

Email: isepulvedaguilar@gmail.com

Received: 20-01-2013

Accepted: 10-08-2013 